\title{
Inter- and Intra-regional Analysis on Spillover Effects across
}

\author{
International Stock Markets
}

\begin{abstract}
This study investigates the inter- and intra-regional spillover effects across international stock markets in New York, Toronto, London, Frankfurt, Paris, Tokyo, Mumbai, Hong Kong, and Shanghai by using both symmetric and asymmetric causality tests. The obtained results show that the inter-regional spillover effects in daytime returns are stronger and more frequent than intra-regional ones. The asymmetric spillover effects are evident for price shocks originating from Asian markets. In addition, the empirical results show that the Chinese stock market is the least integrated market among the investigated international stock markets.
\end{abstract}

JEL classification: C32; G14; G15

Keywords: Spillover Effects; Asymmetric Spillover Effects; Information Transmission Mechanisms; Market Efficiency 


\section{Introduction}

The phenomenon known as the co-movements of equity prices across international stock markets has attracted the attention of financial academics and practitioners over the last four decades, especially in the wake of the recent global financial crisis. A good understanding of cross-market linkages contributes to the pool of academic knowledge in finance and can be beneficial to financial practitioners.

With the availability of high frequency data and advances of econometric theory, the existing literature provides evidence about the presence of return and volatility spillovers across international financial markets, showing that the first and second moments of security prices in one market have a statistically significant impact on price movements in other markets. Engle, Ito, and Lin (1990) introduce the meteor shower hypothesis which assumes that the volatility spills over across markets, i.e. a volatile day in one market is likely to be followed by a volatile day in the subsequently opened market. Hamao, Masulis, and Ng (1990), among others, have found that this "meteor shower effect" is also evident in the return and volatility transmission mechanisms across international stock markets (e.g. see Hamao et al., 1990; 1991; Lin, Engle, and Ito, 1994; Koutmos and Booth, 1995; Koutmos, 1996; Niarchos, Tse, Wu, and Young, 1999; Hsin, 2004; Lee, Rui, and Wang, 2004; Nam, Yuhn, and Kim, 2008; Mukherjee and Mishra, 2010; Yarovaya, Brzeszczynski, and Lau, 2016; Wu, Lau, and Vigne, 2017).

Hamao et al. (1990) are the first who explicitly model the dynamics of the conditional variance by employing an autoregressive conditional heteroskedasticity $(\mathrm{ARCH})$ model while studying the stock market interdependence in the short-run. A new strand of literature has emerged since then, using the ARCH framework to uncover information transmission mechanisms across international stock markets. The ARCHtype models have been traditionally applied by empirical financial economists to study 
the second moment (volatility) of the financial time series. As a result, they are normally regarded as the volatility models which have little relevance to the description of the first moment of time series. However, Hamilton (2010) stresses that even if the primary interest of a research is in the conditional mean rather than the conditional variance, it is still important to correctly model the conditional variance when the ARCH effect has been detected in the data. Hamilton (2010) points out that if one is indeed interested in measuring the magnitude of the coefficients, not only the standard errors but also the parameter estimates themselves should be corrected in light of the dramatic ARCH effect displayed in the data.

While considering the influence of $\mathrm{ARCH}$ effects, this paper examines the direct information transmission mechanisms in equity prices across the world's nine major stock markets using both symmetric and asymmetric causality tests. First, a return spillover model under the ARCH framework is employed to investigate symmetric causal relationships across international stock markets. This study distinguishes between spillovers from markets located in one region (the intra-regional spillover effect) and in different regions (the inter-regional spillover effect). For example, considering trading centres in three main geographic regions, Asia (Tokyo, Mumbai, Hong Kong, and Shanghai), Europe (London, Paris, and Frankfurt) and North America (New York and Toronto) and the time sequence in which they trade, the stock exchanges in the Asian region are open before markets in the other two regions. As a result, the dynamic daytime spillovers from Asian markets to those other markets (interregional spillovers) occur on the same calendar day. On the contrary, the dynamic spillovers within Asian markets (intra-regional spillovers) measure the one-day lagged influence of one market on another and thus do not happen on the same calendar day according to the Greenwich Mean Time (GMT) time scale. 
Second, this paper uses the asymmetric causality test of Hatemi-J (2012) to investigate separate information transmission mechanisms of positive and negative price shocks across markets. Existing literature on international spillover effects normally assumes that the impact of a positive price shock is the same as that of a negative shock. The asymmetry in international spillover effects is still an underexplored area. ${ }^{1}$ There are only few studies that have considered an asymmetric structure in the international spillover literature (e.g., Koutmos and Booth, 1995; Kundu and Sarkar, 2016; Yarovaya, Brzeszczynski, and Lau, 2017). However, none of these studies have explicitly studied asymmetric effects of positive and negative price shocks on equity indices within the context of the causality impacts across international stock markets. ${ }^{2}$

Last, this paper analyses the international spillover effects between developed and emerging markets. The previous literature shows that emerging stock markets have become more integrated with global markets (e.g. Kim and Rogers, 1995; Liu and Pan, 1997; Niarchos et al., 1999; Huang, Yang, and Hu, 2000; Sheng and Tu, 2000; Masih and Masih, 2001; Climent and Meneu, 2003; Hsin, 2004, Wang and Firth, 2004; Lee et al., 2004; Nam et al., 2008; Yarovaya et al., 2016; Bouri, Gupta, Hosseini, and Lau, 2017; Wu et al., 2017; Chen, 2017). However, few studies consider the Chinese and Indian stock markets when investigating information transmission mechanisms between mature and emerging markets, despite the fact that China and India are the only two emerging countries whose stock exchanges are members of " 1 trillion club" with a market capitalisation over one trillion US dollars. ${ }^{3}$ Given the growing influence of the Chinese and Indian economies and increasing liberalisation of the domestic market, it is

\footnotetext{
${ }^{1}$ It is noteworthy that the asymmetry in conditional volatility has been well studied in early research (e.g., Nelson, 1991; Glosten, Jagannathan, and Runkle, 1993). This stream of literature investigates the asymmetric effect of positive and negative price shocks on conditional volatility of returns under the asymmetric GARCH-types models. Our paper investigates the asymmetric effect within the context of international return spillovers, which is an area that is underexplored.

${ }^{2}$ Koutmos and Booth (1995) investigate the asymmetric volatility spillovers across international stock markets. Kundu and Sarkar (2016) test asymmetric spillovers of risk in one market to the mean of another market. Yarovaya et al. (2017) employ the asymmetric causality test to analyse asymmetries in return and volatility spillovers across stock index futures.

${ }^{3}$ The statistics is based the annual statistics guide (2016) from the World Federation of Exchanges (WFE).
} 
interesting to investigate how these markets are correlated to other international stock markets. $^{4}$

This paper contributes to the existing literature in three ways. First, this study presents a thorough inter- and intra-regional analysis on spillover effects across the world's nine major international stock markets. The countries under investigation are among the world's largest economies and include both developed and emerging markets. Second, on analysing return spillover effects across markets, this article compares the ordinary least squared (OLS) estimators with the maximum likelihood (ML) estimators from a GARCH-type model and provides empirical evidence in support of Hamilton (2010). The study highlights the importance of considering the ARCH effect in examining the magnitude and significance of spillover coefficients. Third, this research considers the asymmetry in international spillover effects in the sense that positive and negative price shocks can have different information transmission mechanisms across international stock markets. The asymmetric causality test developed by Hatemi-J (2012) is implemented in this study. The test utilises a bootstrap simulation approach to generate critical values that are robust to the existence of ARCH effects.

The remainder of this paper is as follows. Section 2 presents data and preliminary analysis. Section 3 discusses the econometric model and empirical results. Section 4 offers a summary of findings and concluding remarks.

\section{Data and Preliminary Analysis}

\subsection{Data}

The stock markets (i.e. New York, Toronto, London, Frankfurt, Paris, Tokyo, Mumbai, Hong Kong, and Shanghai) included in this study are the world's major stock exchanges. The market indices chosen to represent these markets are the S\&P 500 (the

\footnotetext{
${ }^{4}$ Chen (2017) suggests that the degree of one country's economy integration into the world economy is positively related to the level of its market comovements with international stock markets.
} 
US), S\&P/TSX (Canada), FTSE100 (the UK), DAX 30 (Germany), CAC 40 (France), NIFTY 500(India), TOPIX (Japan), Shanghai A Share index (China), and Hang Seng (Hong Kong) indices. The daily opening and closing prices of these market indices are used over the period from 1 January 2004 to 31 October 2017.

Table 1 summarises basic statistics of open-to-close (daytime) returns during the sample period. Open-to-close returns (denoted by $R_{t}$ ) are calculated as the difference between natural logarithms of closing and opening prices.

As shown in Table 1, the kurtosis and skewness measures for all series suggest a higher frequency of extreme values for stock returns. In order to test whether returns in each market have a normal distribution, the Jarque-Bera test is conducted. It shows that the null hypothesis that daytime returns are normally distributed is rejected for all eight markets. This finding is broadly consistent with most previous studies that have tested for the normality of daily stock returns (Niarchos et al, 1999; Nam, Yuhn, and Kim, 2008). The Ljung-Box Q-statistics for 16 lags suggest the presence of linear and nonlinear dependence of stock returns in each investigated market. It is noteworthy that the Q-statistics for the squared returns are several times greater than those calculated for returns themselves. This is an indication that the second moment (nonlinear) dependence is far more significant than the first moment dependence. The pattern of large volatility is clustering is evident. As a result, the GARCH-type models appear to be suitable for modelling such phenomenon.

\subsection{Preliminary Analysis}

The simplest method of describing market co-movements adopted by many studies is to report the unconditional correlation coefficient (Pearson's r) matrix in returns across markets of interest. The aim is often to discuss the direction and intensity of return co-movements without necessarily investigating the drivers (causal relationships) 
of such linear dependence. Ideally, this requires the holding periods for comparison to be contemporaneous. Given that the international stock markets operate in different time zones, the daytime returns at the same time period are not synchronised. Cheng and $\mathrm{Ng}$ (1996) suggest that any significant correlation coefficient between inter-regional markets on the same calendar day should be interpreted as evidence of the market that operates earlier causing the one that operates later. For example, the significant correlation coefficient between stock returns of the TOPIX index and the S\&P 500 index implies that the Tokyo market is leading the New York market.

Table 2 reports the cross-correlation coefficients of daytime stock market returns in a matrix. Correlation coefficients between intra-regional markets are in bold and surrounded by thick lines. Since the correlation coefficient matrix is symmetric around the diagonal, results in the lower half of table are reported. All elements on the diagonal of matrix are equal to 1 , implying that one market is perfectly positively correlated with itself. The correlation coefficients are positive and statistically significant in all cases between intra-regional markets, indicating that one market moves, either up or down, the others in the same region are more likely to move in the same direction. The top three pairs in terms of the size of correlation coefficient are Germany-France (Pearson's r of 0.882), Germany-UK (Pearson's r of 0.722), and UK-France (Pearson's r of 0.699), which are all located in the European region. The correlation coefficient between the US and Canadian markets is slightly lower than the top three pairs (Pearson's $r$ of 0.637), but it is considerably higher than those in the Asian region. Comparing to the markets in Europe and North America, the four stock markets in Asia are less correlated, with the Pearson's r ranged from 0.089 (India-Japan) to 0.386 (Hong Kong- China).

For inter-regional markets, there is a general pattern that stock returns in the Asian markets are less related to those in the European and American markets, and the size of Pearson's $r$ is small. The correlation coefficients are statistically insignificant between 
China-France, Japan-France, and China-Germany. ${ }^{5}$ The results could be interpreted as evidence showing that the Shanghai and Tokyo markets have little influence on the subsequently opened Paris stock market, and the Shanghai stock exchange does not lead the Frankfurt market. ${ }^{6}$ By contrast, the correlation coefficients between the US (Canada) and the three European markets are all statistically significant. However, the size of these correlation coefficients is smaller than those between intra-regional markets.

In summary, the results show that cross-correlations are more pronounced and frequent between markets located in one region (intra-regional) than between markets from different regions (inter-regional). ${ }^{7}$ It is not a surprising pattern given the high contemporaneous price co-movements of the markets within the same region (e.g. due to synchronous trading hours, lower geographical distances, closer economic policy coordinations and tighter economic and financial linkages).

Although the cross-correlation coefficient analysis of stock market returns revealed an interesting pattern regarding the extent of market linkages between international stock exchanges, the direction of the causality in the sense of Granger is not fully addressed. The study in next section turns to the investigation of the direct information transmission mechanism across international stock markets.

\section{The Econometric Model}

In order to investigate the transmission of information in daytime returns between markets, a return spillover model is first constructed by including an exogenous variable

\footnotetext{
${ }^{5}$ The correlation coefficient between the Japanese and Canadian markets is only statistically significant at the $10 \%$ level.

${ }^{6}$ It is noteworthy to point out that the results are consistent with the ones suggested by the OLS estimates of a model in which daytime return in the domestic market is a linear function of its preceding daytime return, one-day lagged foreign market daytime return and a constant. The OLS estimates of return spillover coefficients are reported in Table 4.

${ }^{7}$ The observed pattern is consistent with findings from Gebka and Serwa (2007), who study the market linkages between emerging markets in Central and Eastern Europe, Latin America, and South-East Asia after controlling for information originating at home and on developed markets. Their research shows that intra-regional interdependence is more pronounced and frequent than inter-regional one.
} 
(the preceding foreign market return) in the mean equation of the $\operatorname{AR}(1)-\operatorname{GARCH}(1,1)$ model.

The model defines the daytime return in the domestic market as a linear function of its previous daytime return and one-day lagged foreign daytime return. The information contained in the preceding foreign return is included in the model so that the direct impact of potential dynamic return spillover effects from the previously traded foreign stock exchange can be examined. In addition, the model also takes into account the effect of volatility clustering in the return series and defines the conditional variance of the error terms as a linear function of the squared error term and the conditional variance in the last period. The dynamic return spillover model is:

$R_{H, t}=\mu+\alpha R_{H, t-1}+\beta R_{F, t-1}+\epsilon_{t}$,

$h_{t}=a+b \epsilon_{t-1}^{2}+c h_{t-1}$

where $R_{H, t-1}$ is the domestic market daytime return at time $t-1 . R_{F, t-1}$ is the previous daytime return in the foreign market. It represents the new information revealed after the domestic market's close at time $t-1$ and before the open at time $t$. The potential impact of the new information on the current domestic market daytime return is captured by the parameter $\beta$ which is called the dynamic return spillover coefficient. $\beta$ captures the dynamic return spillover effect from the previously opened foreign market to the domestic one. $\beta$ is expected to be positive and statistically significant if the meteor shower effect exists between markets. The conditional variance $\left(h_{t}\right)$ is assumed to be time-varying and follows the GARCH $(1,1)$ process. $^{8}$

\footnotetext{
${ }^{8}$ The models is estimated for by maximising the likelihood function assuming a normal distribution and using the Broyden, Fletcher, Goldfarb and Shanno (BFGS) optimisation algorithm with the robust standard errors described by Bollerslev and Wooldridge (1992).
} 
As suggested by Lin et al. (1994), the return spillover model can also be used to test Granger causality in returns between foreign and domestic markets, which have nonoverlapping trading hours between day $t$ and $t-1$. The question of whether foreign market returns $\left(R_{F}\right)$ Granger-cause domestic market returns $\left(R_{H}\right)$ is to examine if the current domestic market return $\left(R_{H, t}\right)$ can be explained by past foreign market returns ( $\left.R_{F, t-1}\right) . R_{H}$ is said to be Granger-caused by $R_{F}$, if $R_{F}$ occurs before $R_{H}$, and $R_{F}$ helps in the prediction of $R_{H}$ (i.e., if the parameter estimates on past foreign market returns are statistically significant). The statistical inferences of $\beta$ can be regarded as a causality test of whether daytime returns in the previously opened foreign stock markets contain any additional information that helps in the prediction of the domestic market daytime return.

In order to test the asymmetric effects in information transmission mechanisms, this study next adopts the asymmetric causality test of Hatemi-J (2012), which allows for an asymmetric structure in the causality testing and utilises bootstrap simulations to produce critical values that are robust to the non-normality and volatility clustering (e.g., the ARCH effect). Hatemi-J (2012) considers the asymmetric effect in causality by transforming data into the cumulative sums of positive and negative shocks. Assume that variables $y_{1 t}$ and $y_{2 t}$ follow the random walk process and variables $\varepsilon_{1 t}$ and $\varepsilon_{2 t}$ follow the white noise process:

$$
\begin{aligned}
& y_{1 t}=y_{1 t-1}+\varepsilon_{1 t}=y_{1,0}+\sum_{i=1}^{t} \varepsilon_{1 i}^{+}+\sum_{i=1}^{t} \varepsilon_{1 i}^{-} \\
& y_{2 t}=y_{2 t-1}+\varepsilon_{2 t}=y_{2,0}+\sum_{i=1}^{t} \varepsilon_{2 i}^{+}+\sum_{i=1}^{t} \varepsilon_{2 i}^{-},
\end{aligned}
$$

where positive and negative shocks are defined as: $\varepsilon_{1 t}^{+}=\max \left(\varepsilon_{1 i}, 0\right)$, $\varepsilon_{2 t}^{+}=\max \left(\varepsilon_{2 i}, 0\right), \varepsilon_{1 t}^{-}=\min \left(\varepsilon_{1 i}, 0\right)$, and $\varepsilon_{2 t}^{-}=\min \left(\varepsilon_{2 i}, 0\right)$. 
In addition, positive and negative shocks of each underlying variables in a cumulative form can be defined as $y_{1 t}^{+}=\sum_{i=1}^{t} \varepsilon_{1 i}^{+}, y_{1 t}^{-}=\sum_{i=1}^{t} \varepsilon_{1 i}^{-}, y_{2 t}^{+}=\sum_{i=1}^{t} \varepsilon_{2 i}^{+}$, and $y_{2 t}^{-}=\sum_{i=1}^{t} \varepsilon_{2 i}^{-}$

Next, the asymmetric causality testing between these components above can be implemented by using the vector autoregressive model (VAR). For example, the model of testing for causal relationship between positive cumulative shocks is specified as follows:

$$
y_{t}^{+}=v+A_{1} y_{t-1}^{+}+\cdots+A_{p} y_{t-p}^{+}+u_{t}^{+}
$$

where $y_{t}^{+}=\left(y_{1 t}^{+}, y_{2 t}^{+}\right)$is the $2 \times 1$ vector of the variables, $v$ is the $2 \times 1$ vector of intercepts, and $u_{t}^{+}$is a $2 \times 1$ vector of error terms. $A_{j}$ is a $2 \times 2$ matrix of parameters for lag order $r(r=1, \ldots, p)$, where the optimal lag order $\mathrm{p}$ is determined by minimising an information criterion suggested by Hatemi-J (2008).

Last, the null hypothesis of no causality can be tested using the Wald test statistic under the VAR model. A bootstrap simulation approach is used to produce critical values that are robust to non-normality and the ARCH effect.

\section{Empirical Results}

\subsection{Symmetric Testing Results}

Table 3 presents the results of parameter estimates of $\beta$ in the dynamic return spillover model described by Equations (1) and (2). As a comparison, Table 4 reports the results for the OLS estimates of $\beta$ for Equation (1), which assumes time invariant conditional variance. $^{9}$

\footnotetext{
${ }^{9}$ In the presence of heteroskedasticity and autocorrelation, the usual OLS standard errors will be invalid and should not be used for inference. Therefore, the robust standard errors calculated by Newey and West (1987) are used to carry out statistical inferences.
} 
Of particular interest is the pattern that the magnitude of $\beta$ estimated by the return spillover model (under the ARCH framework) is normally much smaller than the one obtained by the OLS estimates. For example, as shown in the first row in Tables 3, under the ARCH framework, the coefficients captured the inter-regional return spillover effects from the UK, France, Germany, the US and Canada to Japan are 0.084, 0.092, 0.083, 0.039, and 0.057, respectively. However, their OLS estimates counterparts (as indicated in the first row in Table 4) are 0.206, 0.195, 0.213, 0.191, and 0.149, respectively. The results show that the magnitude of return spillover effects appears to be considerably smaller than one would infer on the basis of the OLS estimates.

In addition, the interference of $\beta$ is also affected in a substantial way when the $\mathrm{ARCH}$ structure is considered in the model. For example, as shown in the second row in Tables 3, the return spillovers from the UK, France, Germany, and US to Hong Kong are significant at the $1 \%$ level. In contrast, the OLS estimates suggest insignificant results for theses spillovers.

The observed pattern provides strong empirical evidence in favour of Hamilton's (2010) findings, indicating that, in the presence of autoregressive conditional heteroskedasticity $(\mathrm{ARCH})$ in time series (i.e. large outliers and persistent volatility clustering), it is more appropriate to use maximum likelihood estimation in the ARCHtype models rather than the OLS estimation if the research interest is in obtaining accurate estimates of the parameters. The analysis next focuses on an interesting pattern which appears in the dynamic daytime return spillovers from countries located in one region (intra-regional effects) and in different regions (inter-regional effects).

This study finds that intra-regional spillover effects in daytime returns are less frequent and weaker than inter-regional ones. For intra-regional markets, the positive and statistically significant dynamic return spillover is only observed from India to Japan. This is not a surprising pattern since stock daytime returns are more likely to 
transmit across intra-regional markets on the same day, due to factors such as synchronous trading hours, tight economic, financial linkages, and so on. ${ }^{10}$ The statistically insignificant spillover effect between intra-regional markets suggests that stock daytime returns transmit across borders between these markets in an efficient way and without too much delay to the next trading day.

In contrast, due to the non-synchronous trading hours, the inter-regional stock markets open sequentially on the same calendar day. In an efficient market, market opening price should fully and rapidly reflect any information revealed overnight (e.g. information about stock daytime returns in the foreign markets that operate earlier). In other words, the stock daytime returns from the previously opened foreign markets should fully and quickly transmit into the overnight returns in the subsequently opened markets. The contemporaneous return spillover effect between inter-regional markets, which essentially accounts for the impact of overnight foreign information on the opening price in the domestic market, is normally positive and statistically significant. However, it is often the case that market takes time to have such information fully incorporated into the stock price after market opening. There are subsequent spillover effects in the domestic market after the opening of trade. Furthermore, the market that operates later often replicates some behaviour of the market that operates earlier (Gebka and Serwa, 2007). The obtained results show that stock daytime returns transmitting across inter-regional markets are more likely to be in an inefficient manner, and the lagged daytime returns in foreign markets have a positive influence on the current daytime return in the domestic market, which generates the meteor shower effect in daytime returns.

This paper also analyses the international spillover effects between emerging markets in Asia and developed markets in Europe and America. The results in Table 3

\footnotetext{
${ }^{10}$ This is confirmed by the positive and high contemporaneous correlation coefficients between intraregional markets in the preliminary analysis of data in Section 2.
} 
show that the positive return spillovers (i.e., meteor showers) between emerging markets and development markets are mostly unidirectional. The meteor shower effects from Hong Kong and Mumbai to London, Paris, Frankfurt, Toronto, and New York are all statistically significant at the $1 \%$ level. The spillovers from Shanghai to London and New York are also positive and statistically significant at the $1 \%$ level. However, there is little evidence for positive and statistically significant return spillovers from developed to emerging markets. The preceding day's market performance in these developed markets in Europe and America have no statistically positive influence on the next day's stock returns in the Shanghai and Hong Kong stock markets, and the Mumbai stock market only reacts positively to previous day's returns in the Toronto market. This pattern can be explained by work of Chen (2017), which suggests that the regional factor is an important reason for the fluctuations in emerging markets, but not in most developed markets. Moreover, this study finds that the Chinese stock market is the least integrated market among the international stock markets under investigation. The inter-regional daytime return spillover effects from the UK, France, Germany, US, and Canada to China are all statistically insignificant, indicating that the daytime returns in these markets cannot predict the following day's daytime return in the Chinese stock market. Although return spillovers from China to the US, UK, and Canada are positive and statistically significant, it is noteworthy that the size of the spillover effect is markedly smaller comparing to the effects from other markets. For example, as shown in the fifth row in Table 3, the estimated parameters measured the return spillover effects from China to the UK is 0.064 . In contrast, the estimated parameters captured the inter-regional return spillover effects from Japan, Hong Kong, India, US, and Canada to the UK, are $0.215,0.263,0.192,0.345$ and 0.297 , respectively. On average, the return spillover effect from these markets to the UK is four times larger than that from China. The unidirectional dynamic return transmission from China to the other 
countries is not surprising due to the lack of openness and tight financial regulations and controls of capital flows in China. The findings are consistent with the results of Wang and Firth (2004), indicating little evidence of the dynamic return spillovers from the developed markets (Tokyo, New York, and London) to the Shanghai stock market. ${ }^{11}$ It is reasonable to argue that a country with greater restrictions on its financial markets would be less influenced by the dynamic return spillover effects from foreign countries. ${ }^{12}$ On the other hand, the statistically significant dynamic return spillovers from China provide evidence showing that the foreign market investors respond to the information contained in the price movements (i.e. price return) in Chinese stock exchange on the next trading day. However, the spillover effects from China are much less influential than those from the developed markets.

\subsection{Asymmetric Testing Results}

Panels A- I in Table 5 report the results of the asymmetric causality test of Hatemi-J (2012) for all nine markets under investigation. The null hypothesis that negative (positive) price shocks of the foreign markets do not Granger-cause negative (positive) components of the domestic market is tested by using a Wald test with bootstrap critical values $(\mathrm{CV})$ that are robust to non-normality and time-varying volatility clustering. Bootstrap simulations are repeated ten thousand times to produce more precise critical values. The testing is conducted for 72 market pairs for both positive and negative price shocks, thus 144 null hypotheses of non-Granger-causal relationships between markets are tested.

\footnotetext{
${ }^{11}$ Wang and Firth (2004) use the GJR-GARCH(1,1) model to investigate the return and volatility spillover effects across three major developed international stock markets in New York, Tokyo and London and Greater China's four emerging stock markets in Shanghai, Shenzheng, Hong Kong and Taiwan. Wang and Firth (2004) find little evidence of lagged return spillovers from three major developed stock markets to Greater China's four stock markets.

${ }^{12}$ This provides a possible explanation on the low degree of Shanghai stock market comovements with international stock markets, despite Chinese economy is highly integrated into the global economy.
} 
In Table 5, Panels A-D report the results of causality tests with Asian trading centres acting the signal-receiving markets (domestic markets). The null hypotheses that positive (negative) price shocks of European and American markets (the UK, France, Germany, US, and Canada) do not Granger-cause that of Asian markets (Japan, China, Hong Kong, and India) are rejected at the $1 \%$ level of significance for all cases, suggesting a strong inter-regional spillover effects in information transmission mechanisms of both positive and negative shocks. On spillover effects within the Asian region, Japan and India are not influenced by both types of price shock transmission mechanisms from China (as shown in Panels A and D), while positive price innovations in the Chinese stock market are not affected by positive price shocks originating from the other three markets in the region (as shown in Panel C). The intra-regional spillover effects from Hong Kong and India to China are asymmetric in the sense that the Chinese market is susceptible to the transmission mechanisms of negative shocks in Hong Kong and to that of positive ones in India (as shown in Panel B). The results for China show that the Chinese stock market is relatively independent from other markets.

Panels E-I report the results of causality tests with European and American trading centres acting the signal-receiving markets (domestic markets). The inter-regional spillover effects between European and American markets remain strong, and the null hypotheses of non-Granger causalities of positive (negative) shocks are again rejected at the $1 \%$ significance level for market pairs between these two regions. However, the inter-regional spillover effects between Asian stock markets and European and American trading centres are more likely to be asymmetric. The asymmetric spillover effects are present in eleven out of twenty market pairs (China-UK, Japan-UK, IndiaUK, Hong Kong-UK, China-France, China-Germany, India-Germany, China-US, Japan-US, India-US, and Hong Kong-US). The results show that asymmetric spillover effects are evident for the price shocks from Japan, China, India, and Hong Kong to the 
US, UK, France, and Germany, i.e., positive and negative shocks from Asia can have different causal impacts on stock markets located in American and European regions. For example, the results in Panel E show that positive price shocks in China, India and Hong Kong can cause a positive price shock in the UK. However, such causal effects are not statistically significant for negative changes.

\section{Conclusions}

This paper analyses inter- and intra-regional international spillver effects across the world's nine largest stock markets by applying both symmetric and asymmetric causality testing methods.

Using a return spillover model this study shows that the magnitude and significance of the dynamic return spillover coefficients estimated under the ARCH framework are substantially different from the ones obtained by OLS. It provides empirical evidence in support of previous theoretical work by Hamilton (2010), highlighting the importance of considering the ARCH effect in modelling financial data. Furthermore, the symmetric testing results show that inter-regional spillover effects in daytime returns are more frequent and stronger than intra-regional ones. In addition, the study finds that the Chinese stock market is the least integrated market among the investigated international stock markets.

This paper provides empirical evidence for the presence of asymmetric spillover effects across international stock markets and is among the first to analyse the information transmission mechanisms of positive and negative price shocks across equity market indices by adopting the asymmetric causality test of Hatemi-J (2012), which allows for an asymmetric structure in the causality testing and utilises bootstrap simulations to produce critical values that are robust to $\mathrm{ARCH}$ effects. The asymmetric testing results confirm that inter-regional spillover effects in information transmission 
mechanisms are strong for both positive and negative shocks and that the Chinese stock market is relatively independent from other markets. Moreover, this study uncovers the existence of strong asymmetric spillover effects for price shocks originating from Asian stock markets, which is unreported in the existing literature. 
Table 1: Basic Statistics for Daytime Returns

\begin{tabular}{|c|c|c|c|c|c|c|c|}
\hline Stock Markets & Mean (\%) & Std. Dev. & Skewness & Kurtosis & $\mathrm{LB}(16)$ & LB2 (16) & Jarque-Bera \\
\hline UK & 0.014 & 0.011 & -0.162 & 12.011 & $\begin{array}{c}57.446 * * * \\
(0.000)\end{array}$ & $\begin{array}{c}3728.631 * * * \\
(0.000)\end{array}$ & $\begin{array}{l}12226.646 * * * \\
(0.000)\end{array}$ \\
\hline France & -0.021 & 0.011 & -0.342 & 7.694 & $\begin{array}{c}47.086 * * * \\
(0.000)\end{array}$ & $\begin{array}{c}1698.544 * * * \\
(0.000)\end{array}$ & $\begin{array}{c}3383.517 * * * \\
(0.000)\end{array}$ \\
\hline Germany & 0.006 & 0.011 & 0.155 & 11.356 & $\begin{array}{c}44.460 * * * \\
(0.000)\end{array}$ & $\begin{array}{c}1698.544 * * * \\
(0.000)\end{array}$ & $\begin{array}{c}10513.914 * * * \\
(0.000)\end{array}$ \\
\hline US & 0.026 & 0.011 & -0.280 & 16.855 & $\begin{array}{c}77.902 * * * \\
(0.000)\end{array}$ & $\begin{array}{c}4154.022 * * * \\
(0.000)\end{array}$ & $\begin{array}{c}28914.555 * * * \\
(0.000)\end{array}$ \\
\hline Canada & -0.023 & 0.009 & -0.848 & 14.943 & $\begin{array}{c}44.011 * * * \\
(0.000)\end{array}$ & $\begin{array}{c}4846.186^{* * * *} \\
(0.000)\end{array}$ & $\begin{array}{c}21880.241 * * * \\
(0.000)\end{array}$ \\
\hline Japan & -0.033 & 0.010 & -0.528 & 16.695 & $\begin{array}{c}38.036 * * * \\
(0.002)\end{array}$ & $\begin{array}{c}2712.540 * * * \\
(0.000)\end{array}$ & $\begin{array}{c}28372.505 * * * \\
(0.000)\end{array}$ \\
\hline Hong Kong & -0.040 & 0.010 & 0.265 & 19.546 & $\begin{array}{c}110.559 * * * \\
(0.000)\end{array}$ & $\begin{array}{c}2536.245 * * * \\
(0.000)\end{array}$ & $\begin{array}{c}41211.640 * * * \\
(0.000)\end{array}$ \\
\hline China & 0.104 & 0.015 & -0.358 & 7.019 & $\begin{array}{c}31.855 * * * \\
(0.001)\end{array}$ & $\begin{array}{c}1137.803 * * * \\
(0.000)\end{array}$ & $\begin{array}{c}2505.804 * * * \\
(0.000)\end{array}$ \\
\hline India & -0.079 & 0.012 & -0.940 & 11.036 & $\begin{array}{c}51.095 * * * \\
(0.001)\end{array}$ & $\begin{array}{c}1478.468 * * * \\
(0.000)\end{array}$ & $\begin{array}{c}10242.220 * * * \\
(0.000)\end{array}$ \\
\hline
\end{tabular}


Table 2: Correlation Coefficients (Pearson's r) Matrix for Returns

\begin{tabular}{|c|c|c|c|c|c|c|c|c|c|}
\hline $\begin{array}{l}\text { Person's r } \\
\text { between }\end{array}$ & Japan & Hong Kong & China & India & UK & France & Germany & US & Canada \\
\hline Japan & $\begin{array}{c}1.000 \\
---\end{array}$ & & & & & & & & \\
\hline Hong Kong & $\begin{array}{c}0.305 * * * \\
(0.000)\end{array}$ & $\begin{array}{c}1.000 \\
---\end{array}$ & & & & & & & \\
\hline China & $\begin{array}{c}0.152 * * * \\
(0.000)\end{array}$ & $\begin{array}{c}0.386 * * * \\
(0.000)\end{array}$ & $\begin{array}{c}1.000 \\
---\end{array}$ & & & & & & \\
\hline India & $\begin{array}{c}0.089 * * * \\
(0.000)\end{array}$ & $\begin{array}{c}0.321 * * * \\
(0.000)\end{array}$ & $\begin{array}{c}0.110 * * * \\
(0.000)\end{array}$ & $\begin{array}{c}1.000 \\
---\end{array}$ & & & & & \\
\hline UK & $\begin{array}{c}0.286 * * * \\
(0.000)\end{array}$ & $\begin{array}{c}0.287 * * * \\
(0.000)\end{array}$ & $\begin{array}{c}0.105 * * * \\
(0.000)\end{array}$ & $\begin{array}{c}0.272 * * * \\
(0.000)\end{array}$ & $\begin{array}{c}1.000 \\
---\end{array}$ & & & & \\
\hline France & $\begin{array}{c}0.015 \\
(0.3822)\end{array}$ & $\begin{array}{c}0.107 * * * \\
(0.000)\end{array}$ & $\begin{array}{c}-0.012 \\
(0.4760)\end{array}$ & $\begin{array}{c}0.231 * * * \\
(0.000)\end{array}$ & $\begin{array}{c}0.699 * * * \\
(0.000)\end{array}$ & $\begin{array}{c}1.000 \\
---\end{array}$ & & & \\
\hline Germany & $\begin{array}{c}0.076 * * * \\
(0.000)\end{array}$ & $\begin{array}{c}0.161 * * * \\
(0.000)\end{array}$ & $\begin{array}{c}0.011 \\
(0.5239)\end{array}$ & $\begin{array}{c}0.242 * * * \\
(0.000)\end{array}$ & $\begin{array}{c}0.722 * * * \\
(0.000)\end{array}$ & $\begin{array}{c}0.882 * * * \\
(0.000)\end{array}$ & $\begin{array}{c}1.000 \\
---\end{array}$ & & \\
\hline US & $\begin{array}{c}0.136 * * * \\
(0.000)\end{array}$ & $\begin{array}{c}0.281 * * * \\
(0.000)\end{array}$ & $\begin{array}{c}0.087 * * * \\
(0.000)\end{array}$ & $\begin{array}{c}0.212 * * * \\
(0.000)\end{array}$ & $\begin{array}{c}0.538 * * * \\
(0.000)\end{array}$ & $\begin{array}{c}0.579 * * * \\
(0.000)\end{array}$ & $\begin{array}{c}0.577 * * * \\
(0.000)\end{array}$ & $\begin{array}{c}1.000 \\
---\end{array}$ & \\
\hline Canada & $\begin{array}{c}0.028 * \\
(0.0955)\end{array}$ & $\begin{array}{c}0.123 * * * \\
(0.000)\end{array}$ & $\begin{array}{l}0.043 * * \\
(0.0102)\end{array}$ & $\begin{array}{c}0.107 * * * \\
(0.000)\end{array}$ & $\begin{array}{c}0.327 * * * \\
(0.000)\end{array}$ & $\begin{array}{c}0.381 * * * \\
(0.000)\end{array}$ & $\begin{array}{c}0.333 * * * \\
(0.000)\end{array}$ & $\begin{array}{c}0.637 * * * \\
(0.000)\end{array}$ & $\begin{array}{c}1.000 \\
-.-\end{array}$ \\
\hline
\end{tabular}

Notes: (1) Correlation coefficients between intra-regional markets are in bold and surrounded by thick lines. (2) Values in the upper half of table are not reported due to symmetry of the correlation coefficient matrix. (3) The p-values reported in parentheses are for testing the null hypothesis that correlation coefficient is equal to zero. The tstatistic is computed as $t=\mathrm{r} \sqrt{(n-2) /(1-r)^{2}}$, where $\mathrm{n}$ is sample size and $\mathrm{r}$ is correlation coefficient (Pearson's r). P-values are obtained from a t-distribution with $\mathrm{n}$-2 degrees-of-freedom. 
Table 3: Results of Return Causality (Spillover) Tests under GARCH

\begin{tabular}{|c|c|c|c|c|c|c|c|c|c|}
\hline Caused & Japan & Hong Kong & China & India & UK & France & Germany & US & Canada \\
\hline Japan & --- & $\begin{array}{c}-0.002 \\
(0.8956)\end{array}$ & $\begin{array}{l}-0.017 \\
(0.129) \\
\end{array}$ & $\begin{array}{c}0.044 * * * \\
(0.001)\end{array}$ & $\begin{array}{c}0.084 * * * \\
(0.000)\end{array}$ & $\begin{array}{c}0.092 * * * \\
(0.000)\end{array}$ & $\begin{array}{c}0.083 * * * \\
(0.000)\end{array}$ & $\begin{array}{c}0.039 * * \\
(0.025)\end{array}$ & $\begin{array}{c}0.057 * * \\
(0.014)\end{array}$ \\
\hline Hong Kong & $\begin{array}{c}-0.035 * * \\
(0.037)\end{array}$ & --- & $\begin{array}{c}-0.024 * * \\
(0.024)\end{array}$ & $\begin{array}{l}0.0155 \\
(0.365)\end{array}$ & $\begin{array}{c}-0.042 * * \\
(0.011)\end{array}$ & $\begin{array}{c}-0.040 * * * \\
(0.004)\end{array}$ & $\begin{array}{c}-0.039 * * * \\
(0.006)\end{array}$ & $\begin{array}{c}-0.076 * * * \\
(0.000)\end{array}$ & $\begin{array}{l}-0.011 \\
(0.588)\end{array}$ \\
\hline China & $\begin{array}{c}-0.072 * * * \\
(0.001)\end{array}$ & $\begin{array}{c}-0.060 * * \\
(0.031)\end{array}$ & --- & $\begin{array}{l}-0.008 \\
(0.694)\end{array}$ & $\begin{array}{c}-0.014 \\
(0.535)\end{array}$ & $\begin{array}{c}0.004 \\
(0.861)\end{array}$ & $\begin{array}{l}0.0048 \\
(0.824)\end{array}$ & $\begin{array}{l}-0.019 \\
(0.438)\end{array}$ & $\begin{array}{c}0.044 \\
(0.110)\end{array}$ \\
\hline India & $\begin{array}{l}-0.035^{*} \\
(0.051)\end{array}$ & $\begin{array}{c}-0.072 * * * \\
(0.001)\end{array}$ & $\begin{array}{c}-0.029 * * \\
(0.020)\end{array}$ & --- & $\begin{array}{c}-0.050 * * \\
(0.011)\end{array}$ & $\begin{array}{c}-0.035 * * \\
(0.032)\end{array}$ & $\begin{array}{c}-0.028 * \\
(0.088)\end{array}$ & $\begin{array}{l}-0.032 \\
(0.104)\end{array}$ & $\begin{array}{c}0.052 * * \\
(0.030)\end{array}$ \\
\hline UK & $\begin{array}{c}0.215 * * * \\
(0.000)\end{array}$ & $\begin{array}{c}0.263 * * * \\
(0.000)\end{array}$ & $\begin{array}{c}0.064 * * * \\
(0.000)\end{array}$ & $\begin{array}{c}0.192 * * * \\
(0.000) \\
\end{array}$ & --- & $\begin{array}{c}0.000 \\
(0.998) \\
\end{array}$ & $\begin{array}{l}-0.004 \\
(0.877) \\
\end{array}$ & $\begin{array}{c}0.345 * * * \\
(0.000)\end{array}$ & $\begin{array}{c}0.297 * * * \\
(0.000)\end{array}$ \\
\hline France & $\begin{array}{c}0.023 \\
(0.337)\end{array}$ & $\begin{array}{c}0.102 * * * \\
(0.000)\end{array}$ & $\begin{array}{c}0.005 \\
(0.708) \\
\end{array}$ & $\begin{array}{c}0.1568 * * * \\
(0.000)\end{array}$ & $\begin{array}{c}0.013 \\
(0.622) \\
\end{array}$ & --- & $\begin{array}{c}0.041 \\
(0.279) \\
\end{array}$ & $\begin{array}{c}-0.007 \\
(0.771) \\
\end{array}$ & $\begin{array}{c}0.005 \\
(0.850) \\
\end{array}$ \\
\hline Germany & $\begin{array}{c}0.026 \\
(0.304) \\
\end{array}$ & $\begin{array}{c}0.129 * * * \\
(0.000)\end{array}$ & $\begin{array}{c}0.016 \\
(0.254) \\
\end{array}$ & $\begin{array}{c}0.181 * * * \\
(0.000)\end{array}$ & $\begin{array}{c}-0.0378 \\
(0.181) \\
\end{array}$ & $\begin{array}{c}-0.095 * * \\
(0.014) \\
\end{array}$ & --- & $\begin{array}{c}0.054 * * \\
(0.028)\end{array}$ & $\begin{array}{c}0.036 \\
(0.202) \\
\end{array}$ \\
\hline US & $\begin{array}{c}0.121 * * * \\
(0.000)\end{array}$ & $\begin{array}{c}0.173 * * * \\
(0.000)\end{array}$ & $\begin{array}{c}0.050 * * * \\
(0.000)\end{array}$ & $\begin{array}{c}0.102 * * * \\
(0.000)\end{array}$ & N/A & $\mathrm{N} / \mathrm{A}$ & N/A & --- & $\begin{array}{l}-0.003 \\
(0.923)\end{array}$ \\
\hline Canada & $\begin{array}{c}0.042 * * * \\
(0.0025)\end{array}$ & $\begin{array}{c}0.090 * * * \\
(0.000)\end{array}$ & $\begin{array}{c}0.028 * * * \\
(0.0022)\end{array}$ & $\begin{array}{c}0.057 * * * \\
(0.000)\end{array}$ & N/A & $\mathrm{N} / \mathrm{A}$ & $\mathrm{N} / \mathrm{A}$ & $\begin{array}{l}-0.002 \\
(0.936)\end{array}$ & --- \\
\hline
\end{tabular}

Notes: (1) Asterisks ***, and *** denote estimated $\beta$ is statistically significant at the $1 \%, 5 \%$ and $10 \%$ levels, respectively. P-values are reported in parentheses. Inferences of $\beta$ under GARCH reflect standard errors computed using the inference procedures developed by Bollerslev and Wooldridge (1992), which are robust to non-normality of the residuals. (2) The open-to-close return spillovers cannot be explicitly investigated due to two hours of overlapping trading time between the late afternoon in the European stock markets and early morning in the North American markets. The study excludes this sequence and does not report the results in tables. (3) The return spillover effects between intra-regional markets are in bold and surrounded by thick lines. 
Table 4: Results of Return Causality (Spillover) Tests under OLS

\begin{tabular}{|c|c|c|c|c|c|c|c|c|c|}
\hline Caused & Japan & Hong Kong & China & India & UK & France & Germany & US & Canada \\
\hline Japan & --- & $\begin{array}{c}0.073 * * \\
(0.05)\end{array}$ & $\begin{array}{l}-0.012 \\
(0.394) \\
\end{array}$ & $\begin{array}{c}0.095 * * * \\
(0.000)\end{array}$ & $\begin{array}{c}0.206 * * * \\
(0.000)\end{array}$ & $\begin{array}{c}0.195 * * * \\
(0.000)\end{array}$ & $\begin{array}{c}0.213 * * * \\
(0.000)\end{array}$ & $\begin{array}{c}0.191 * * * \\
(0.000)\end{array}$ & $\begin{array}{c}0.149 * * * \\
(0.001)\end{array}$ \\
\hline Hong Kong & $\begin{array}{l}-0.027 \\
(0.406)\end{array}$ & --- & $\begin{array}{c}-0.037 * * \\
(0.014)\end{array}$ & $\begin{array}{c}0.023 \\
(0.235)\end{array}$ & $\begin{array}{c}-0.034 \\
(0.402)\end{array}$ & $\begin{array}{c}-0.035 \\
(0.131) \\
\end{array}$ & $\begin{array}{c}-0.014 \\
(0.710)\end{array}$ & $\begin{array}{c}-0.093 * * * \\
(0.000)\end{array}$ & $\begin{array}{l}-0.065 \\
(0.275)\end{array}$ \\
\hline China & $\begin{array}{c}-0.077 * * * \\
(0.009)\end{array}$ & $\begin{array}{c}-0.092 * * * \\
(0.009)\end{array}$ & --- & $\begin{array}{l}-0.013 \\
(0.594)\end{array}$ & $\begin{array}{c}-0.007 \\
(0.838)\end{array}$ & $\begin{array}{c}0.006 \\
(0.840)\end{array}$ & $\begin{array}{l}-0.001 \\
(0.978)\end{array}$ & $\begin{array}{c}-0.047 \\
(0.101)\end{array}$ & $\begin{array}{l}-0.019 \\
(0.646)\end{array}$ \\
\hline India & $\begin{array}{l}-0.002 \\
(0.929)\end{array}$ & $\begin{array}{c}-0.0997 * * * \\
(0.004)\end{array}$ & $\begin{array}{l}-0.026 \\
(0.142)\end{array}$ & --- & $\begin{array}{c}-0.069 * * \\
(0.005)\end{array}$ & $\begin{array}{l}-0.05 * \\
(0.051)\end{array}$ & $\begin{array}{c}-0.047 * \\
(0.056)\end{array}$ & $\begin{array}{c}-0.064 * * \\
(0.012)\end{array}$ & $\begin{array}{c}0.032 \\
(0.370)\end{array}$ \\
\hline UK & $\begin{array}{c}0.334 * * * \\
(0.000)\end{array}$ & $\begin{array}{c}0.316 * * * \\
(0.000) \\
\end{array}$ & $\begin{array}{c}0.079 * * * \\
(0.000)\end{array}$ & $\begin{array}{c}0.249 * * * \\
(0.000)\end{array}$ & --- & $\begin{array}{c}0.010 \\
(0.864) \\
\end{array}$ & $\begin{array}{c}0.072 \\
(0.239) \\
\end{array}$ & $\begin{array}{c}0.413 * * * \\
(0.000)\end{array}$ & $\begin{array}{c}0.334 * * * \\
(0.000)\end{array}$ \\
\hline France & $\begin{array}{c}0.032 \\
(0.122)\end{array}$ & $\begin{array}{c}0.113 * * * \\
(0.0048)\end{array}$ & $\begin{array}{c}-0.009 \\
(0.628)\end{array}$ & $\begin{array}{c}0.206 * * * \\
(0.000)\end{array}$ & $\begin{array}{c}0.042 \\
(0.285)\end{array}$ & --- & $\begin{array}{c}0.127 * * \\
(0.019)\end{array}$ & $\begin{array}{c}0.051 \\
(0.199)\end{array}$ & $\begin{array}{c}0.044 \\
(0.236)\end{array}$ \\
\hline Germany & $\begin{array}{c}0.085 * * * \\
(0.005) \\
\end{array}$ & $\begin{array}{c}0.183 * * * \\
(0.000) \\
\end{array}$ & $\begin{array}{c}0.008 \\
(0.645) \\
\end{array}$ & $\begin{array}{c}0.229 * * * \\
(0.000) \\
\end{array}$ & $\begin{array}{l}-0.085 \\
(0.181) \\
\end{array}$ & $\begin{array}{c}-0.241 * * * \\
(0.009)\end{array}$ & --- & $\begin{array}{c}0.0966 * * \\
(0.012)\end{array}$ & $\begin{array}{c}0.055 \\
(0.238) \\
\end{array}$ \\
\hline US & $\begin{array}{c}0.173 * * * \\
(0.000)\end{array}$ & $\begin{array}{c}0.297 * * * \\
(0.000)\end{array}$ & $\begin{array}{c}0.062 * * * \\
(0.003)\end{array}$ & $\begin{array}{c}0.186 * * * \\
(0.000)\end{array}$ & N/A & $\mathrm{N} / \mathrm{A}$ & N/A & --- & $\begin{array}{l}-0.055 \\
(0.511)\end{array}$ \\
\hline Canada & $\begin{array}{c}0.027 \\
(0.473)\end{array}$ & $\begin{array}{c}0.106 * * * \\
(0.000)\end{array}$ & $\begin{array}{c}0.025 \\
(0.106)\end{array}$ & $\begin{array}{c}0.078 * * * \\
(0.0005)\end{array}$ & N/A & N/A & N/A & $\begin{array}{c}0.006 \\
(0.914)\end{array}$ & --- \\
\hline
\end{tabular}

Notes: (1) Asterisks *,**, and *** denote estimated $\beta$ is statistically significant at the $1 \%, 5 \%$ and $10 \%$ levels, respectively. P-values are reported in parentheses. Inferences of $\beta$ under OLS are based on Newey and West (1987) heteroskedasticity-autocorrelation-consistent standard errors. (2) The open-to-close return spillovers cannot be explicitly investigated due to two hours of overlapping trading time between the late afternoon in the European stock markets and early morning in the North American markets. The study excludes this sequence and does not report the results in tables. (3) The return spillover effects between intra-regional markets are in bold and surrounded by thick lines. 
Table 5: Results for Asymmetric Causality Tests

Panel A: Japan as the domestic market

\begin{tabular}{|c|c|c|c|c|c|}
\hline Hypothesis & Test Value & $\begin{array}{l}\text { Bootstrap } \\
\text { CV at } 1 \%\end{array}$ & $\begin{array}{l}\text { Bootstrap } \\
\text { CV at } 5 \%\end{array}$ & $\begin{array}{l}\text { Bootstrap } \\
\mathrm{CV} \text { at } 10 \%\end{array}$ & Conclusions \\
\hline $\begin{array}{l}\mathrm{HK}+\neq> \\
\mathrm{JP}+\end{array}$ & $82.836^{* * *}$ & 11.794 & 7.647 & 5.900 & $\begin{array}{l}\mathrm{HK}+=> \\
\mathrm{JP}+\end{array}$ \\
\hline $\begin{array}{l}\text { HK- } \neq> \\
\text { JP- }\end{array}$ & $44.844 * * *$ & 14.604 & 9.961 & 7.855 & $\begin{array}{l}\text { HK- => } \\
\text { JP- }\end{array}$ \\
\hline $\begin{array}{l}\mathrm{CHN}+\neq> \\
\mathrm{JP}+\end{array}$ & 2.722 & 9.379 & 6.088 & 4.730 & $\begin{array}{l}\mathrm{CHN}+\neq> \\
\mathrm{JP}+\end{array}$ \\
\hline $\begin{array}{l}\text { CHN- } \neq> \\
\text { JP- }\end{array}$ & 5.521 & 13.253 & 9.167 & 7.762 & $\begin{array}{l}\text { CHN- } \neq> \\
\text { JP- }\end{array}$ \\
\hline $\begin{array}{l}\text { IND }+\neq> \\
\text { JP+ }\end{array}$ & $73.526 * * *$ & 9.235 & 5.871 & 4.292 & $\begin{array}{l}\text { IND+=> } \\
\mathrm{JP}+\end{array}$ \\
\hline $\begin{array}{l}\text { IND- } \neq> \\
\text { JP- }\end{array}$ & $119.808 * * *$ & 10.064 & 7.814 & 5.810 & $\begin{array}{l}\text { IND- => } \\
\text { JP- }\end{array}$ \\
\hline $\begin{array}{l}\mathrm{UK}+\neq> \\
\mathrm{JP}+\end{array}$ & $670.495 * * *$ & 10.322 & 6.346 & 4.740 & $\begin{array}{l}\mathrm{UK}+=> \\
\mathrm{JP}+\end{array}$ \\
\hline $\begin{array}{l}\text { UK- } \neq> \\
\text { JP- }\end{array}$ & $580.790 * * *$ & 14.859 & 9.844 & 7.662 & $\begin{array}{l}\text { UK- }=> \\
\text { JP- }\end{array}$ \\
\hline $\begin{array}{l}\mathrm{FRA}+\neq> \\
\mathrm{JP}+\end{array}$ & $711.985 * * *$ & 9.451 & 6.193 & 4.855 & $\begin{array}{l}\text { FRA+ => } \\
\text { JP+ }\end{array}$ \\
\hline $\begin{array}{l}\text { FRA- } \neq> \\
\text { JP- }\end{array}$ & $546.418 * * *$ & 12.819 & 9.272 & 7.746 & $\begin{array}{l}\text { FRA- => } \\
\text { JP- }\end{array}$ \\
\hline $\begin{array}{l}\text { GER+ } \neq> \\
\text { JP+ }\end{array}$ & $634.959 * * *$ & 9.458 & 5.896 & 4.523 & $\begin{array}{l}\text { GER+ => } \\
\text { JP+ }\end{array}$ \\
\hline $\begin{array}{l}\text { GER- } \neq> \\
\text { JP- }\end{array}$ & $580.579 * * *$ & 13.702 & 9.574 & 7.664 & $\begin{array}{l}\text { GER- => } \\
\text { JP- }\end{array}$ \\
\hline $\begin{array}{l}\text { US }+\neq> \\
\mathrm{JP}+\end{array}$ & $889.729 * * *$ & 13.405 & 9.300 & 7.504 & $\begin{array}{l}\text { US+ => } \\
\mathrm{JP}+\end{array}$ \\
\hline $\begin{array}{l}\text { US- } \neq> \\
\text { JP- }\end{array}$ & $1017.159 * * *$ & 14.115 & 9.618 & 7.754 & $\begin{array}{l}\text { US- => } \\
\text { JP- }\end{array}$ \\
\hline $\begin{array}{l}\mathrm{CAN}+\neq> \\
\mathrm{JP}+\end{array}$ & $400.777 * * *$ & 10.816 & 5.699 & 4.460 & $\begin{array}{l}\text { CAN+ => } \\
\text { JP+ }\end{array}$ \\
\hline $\begin{array}{l}\text { CAN- } \neq> \\
\text { JP- }\end{array}$ & $629.383 * * *$ & 13.603 & 9.315 & 7.623 & $\begin{array}{l}\text { CAN- => } \\
\text { JP- }\end{array}$ \\
\hline
\end{tabular}

Panel B: China as the domestic market

\begin{tabular}{llllll}
\hline Hypothesis & Test Value & $\begin{array}{l}\text { Bootstrap } \\
\text { CV at 1\% }\end{array}$ & $\begin{array}{l}\text { Bootstrap } \\
\text { CV at 5\% }\end{array}$ & $\begin{array}{l}\text { Bootstrap } \\
\text { CV at 10\% }\end{array}$ & Conclusions \\
\hline $\begin{array}{l}\mathrm{HK}+\neq> \\
\mathrm{CHN}+\end{array}$ & 1.668 & 11.329 & 8.122 & 6.186 & $\begin{array}{l}\mathrm{HK}+\neq> \\
\mathrm{CHN}+\end{array}$ \\
\hline $\begin{array}{l}\mathrm{HK}-\neq> \\
\mathrm{CHN}-\end{array}$ & $21.442^{* * *}$ & 13.338 & 9.508 & 7.664 & $\begin{array}{l}\mathrm{HK}-=> \\
\mathrm{CHN}-\end{array}$ \\
\hline $\mathrm{JP}+\neq>$ & 0.114 & 9.063 & 6.572 & 4.843 & $\mathrm{JP}+\neq>$ \\
\hline
\end{tabular}




\begin{tabular}{|c|c|c|c|c|c|}
\hline $\mathrm{CHN}+$ & & & & & $\mathrm{CHN}+$ \\
\hline $\begin{array}{l}\text { JP- } \neq> \\
\text { CHN- }\end{array}$ & 5.878 & 14.326 & 10.161 & 7.917 & $\begin{array}{l}\text { JP- } \neq> \\
\text { CHN- }\end{array}$ \\
\hline $\begin{array}{l}\text { IND }+\neq> \\
\mathrm{CHN}+\end{array}$ & 2.090 & 10.103 & 6.182 & 4.642 & $\begin{array}{l}\text { IND }+\neq> \\
\mathrm{CHN}+\end{array}$ \\
\hline $\begin{array}{l}\text { IND- } \neq> \\
\text { CHN- }\end{array}$ & $40.305^{* * *}$ & 15.041 & 9.799 & 7.975 & $\begin{array}{l}\text { IND- }=> \\
\text { CHN- }\end{array}$ \\
\hline $\begin{array}{l}\mathrm{UK}+\neq> \\
\mathrm{CHN}+\end{array}$ & $30.590 * * *$ & 9.634 & 6.066 & 4.580 & $\begin{array}{l}\mathrm{UK}+=> \\
\mathrm{CHN}+\end{array}$ \\
\hline $\begin{array}{l}\mathrm{UK}-\neq> \\
\mathrm{CHN}-\end{array}$ & $80.140 * * *$ & 13.683 & 9.775 & 7.999 & $\begin{array}{l}\text { UK- }=> \\
\text { CHN- }\end{array}$ \\
\hline $\begin{array}{l}\mathrm{FRA}+\neq> \\
\mathrm{CHN}+\end{array}$ & $22.372 * * *$ & 9.358 & 6.014 & 4.436 & $\begin{array}{l}\text { FRA+=> } \\
\mathrm{CHN}+\end{array}$ \\
\hline $\begin{array}{l}\text { FRA- } \neq> \\
\text { CHN- }\end{array}$ & $62.261 * * *$ & 12.949 & 9.956 & 8.026 & $\begin{array}{l}\text { FRA-=> } \\
\text { CHN- }\end{array}$ \\
\hline $\begin{array}{l}\mathrm{GER}+\neq> \\
\mathrm{CHN}+\end{array}$ & $16.305 * * *$ & 8.515 & 5.938 & 4.542 & $\begin{array}{l}\text { GER+ => } \\
\mathrm{CHN}+\end{array}$ \\
\hline $\begin{array}{l}\text { GER- } \neq> \\
\text { CHN- }\end{array}$ & $70.534 * * *$ & 11.917 & 9.471 & 8.070 & $\begin{array}{l}\text { GER- => } \\
\text { CHN- }\end{array}$ \\
\hline 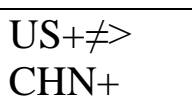 & $25.701 * * *$ & 15.325 & 9.709 & 7.989 & $\begin{array}{l}\text { US+=> } \\
\mathrm{CHN}+\end{array}$ \\
\hline $\begin{array}{l}\text { US- } \neq> \\
\text { CHN- }\end{array}$ & $111.244 * * *$ & 12.874 & 9.355 & 7.507 & $\begin{array}{l}\text { US- }=> \\
\text { CHN- }\end{array}$ \\
\hline $\begin{array}{l}\mathrm{CAN}+\neq> \\
\mathrm{CHN}+\end{array}$ & $16.130 * * *$ & 9.824 & 6.430 & 4.758 & $\begin{array}{l}\mathrm{CAN}+=> \\
\mathrm{CHN}+\end{array}$ \\
\hline $\begin{array}{l}\text { CAN- } \neq> \\
\text { CHN- }\end{array}$ & $78.570 * * *$ & 13.150 & 9.091 & 7.713 & $\begin{array}{l}\text { CAN- => } \\
\text { CHN- }\end{array}$ \\
\hline
\end{tabular}

Panel C: Hong Kong as the domestic market

\begin{tabular}{|c|c|c|c|c|c|}
\hline Hypothesis & Test Value & $\begin{array}{l}\text { Bootstrap } \\
\text { CV at } 1 \%\end{array}$ & $\begin{array}{l}\text { Bootstrap } \\
\text { CV at 5\% }\end{array}$ & $\begin{array}{l}\text { Bootstrap } \\
\text { CV at } 10 \%\end{array}$ & Conclusions \\
\hline $\begin{array}{l}\mathrm{CHN}+\neq> \\
\mathrm{HK}+\end{array}$ & $15.073 * * *$ & 11.857 & 7.692 & 6.036 & $\begin{array}{l}\mathrm{CHN}+=> \\
\mathrm{HK}+\end{array}$ \\
\hline $\begin{array}{l}\text { CHN- } \neq> \\
\text { HK- }\end{array}$ & $11.159 * *$ & 13.362 & 9.462 & 7.970 & $\begin{array}{l}\mathrm{CHN}-=> \\
\mathrm{HK}-\end{array}$ \\
\hline $\begin{array}{l}\mathrm{JP}+\neq> \\
\mathrm{HK}+\end{array}$ & 3.939 & 11.570 & 7.899 & 6.489 & $\begin{array}{l}\mathrm{JP}+\neq> \\
\mathrm{HK}+\end{array}$ \\
\hline $\begin{array}{l}\text { JP- } \neq> \\
\text { HK- }\end{array}$ & 7.187 & 14.182 & 10.415 & 8.429 & $\begin{array}{l}\text { JP- } \neq> \\
\text { HK- }\end{array}$ \\
\hline $\begin{array}{l}\text { IND }+\neq> \\
\mathrm{HK}+\end{array}$ & $16.420 * * *$ & 12.156 & 7.984 & 6.130 & $\begin{array}{l}\text { IND+ => } \\
\mathrm{HK}+\end{array}$ \\
\hline $\begin{array}{l}\text { IND- } \neq> \\
\text { HK- }\end{array}$ & $112.712 * * *$ & 15.091 & 9.306 & 7.855 & $\begin{array}{l}\text { IND- => } \\
\text { HK- }\end{array}$ \\
\hline $\begin{array}{l}\mathrm{UK}+\neq> \\
\mathrm{HK}+\end{array}$ & $365.055^{* * *}$ & 11.935 & 7.621 & 5.992 & $\begin{array}{l}\mathrm{UK}+=> \\
\mathrm{HK}+\end{array}$ \\
\hline $\begin{array}{l}\text { UK- } \neq> \\
\text { HK- }\end{array}$ & $434.335 * * *$ & 14.795 & 9.473 & 7.705 & $\begin{array}{l}\text { UK- => } \\
\text { HK- }\end{array}$ \\
\hline
\end{tabular}




\begin{tabular}{|c|c|c|c|c|c|}
\hline $\begin{array}{l}\text { FRA }+\neq> \\
\mathrm{HK}+\end{array}$ & $341.334 * * *$ & 14.573 & 9.513 & 7.682 & $\begin{array}{l}\text { FRA }+=> \\
\text { HK }+\end{array}$ \\
\hline $\begin{array}{l}\text { FRA- } \neq> \\
\text { HK- }\end{array}$ & $318.524 * * *$ & 11.133 & 7.588 & 6.158 & $\begin{array}{l}\text { FRA- => } \\
\text { HK- }\end{array}$ \\
\hline $\begin{array}{l}\text { GER+ } \neq> \\
\mathrm{HK}+\end{array}$ & $234.089 * * *$ & 12.808 & 7.758 & 6.210 & $\begin{array}{l}\text { GER+ => } \\
\text { HK+ }\end{array}$ \\
\hline $\begin{array}{l}\text { GER- } \neq> \\
\text { HK- }\end{array}$ & $435.293 * * *$ & 13.789 & 9.500 & 7.645 & $\begin{array}{l}\text { GER- => } \\
\text { HK- }\end{array}$ \\
\hline $\begin{array}{l}\text { US }+\neq> \\
\mathrm{HK}+\end{array}$ & $487.217 * * *$ & 14.912 & 9.914 & 8.007 & $\begin{array}{l}\text { US+ => } \\
\mathrm{HK}+\end{array}$ \\
\hline $\begin{array}{l}\text { US- } \neq> \\
\text { HK- }\end{array}$ & $959.020 * * *$ & 14.586 & 9.303 & 7.579 & $\begin{array}{l}\text { US- => } \\
\text { HK- }\end{array}$ \\
\hline $\begin{array}{l}\mathrm{CAN}+\neq> \\
\mathrm{HK}+\end{array}$ & $333.499 * * *$ & 13.141 & 8.146 & 6.401 & $\begin{array}{l}\mathrm{CAN}+=> \\
\mathrm{HK}+\end{array}$ \\
\hline $\begin{array}{l}\text { CAN- } \neq> \\
\text { HK- }\end{array}$ & $647.789 * * *$ & 16.171 & 9.355 & 7.621 & $\begin{array}{l}\text { CAN- }=> \\
\text { HK- }\end{array}$ \\
\hline
\end{tabular}

Panel D: India as the domestic market

\begin{tabular}{|c|c|c|c|c|c|}
\hline Hypothesis & Test Value & $\begin{array}{l}\text { Bootstrap } \\
\text { CV at } 1 \%\end{array}$ & $\begin{array}{l}\text { Bootstrap } \\
\text { CV at 5\% }\end{array}$ & $\begin{array}{l}\text { Bootstrap } \\
\text { CV at } 10 \%\end{array}$ & Conclusions \\
\hline $\begin{array}{l}\mathrm{CHN}+\neq> \\
\text { IND+ }\end{array}$ & 3.172 & 9.554 & 5.940 & 4.456 & $\begin{array}{l}\mathrm{CHN}+\neq> \\
\mathrm{IND}+\end{array}$ \\
\hline $\begin{array}{l}\text { CHN- } \neq> \\
\text { IND- }\end{array}$ & 7.514 & 14.571 & 9.403 & 7.964 & $\begin{array}{l}\text { CHN- } \neq> \\
\text { IND- }\end{array}$ \\
\hline $\begin{array}{l}\mathrm{JP}+\neq> \\
\text { IND+ }\end{array}$ & $4.941 *$ & 10.129 & 6.184 & 4.804 & $\begin{array}{l}\text { JP+ => } \\
\text { IND+ }\end{array}$ \\
\hline $\begin{array}{l}\text { JP- } \neq> \\
\text { IND- }\end{array}$ & $22.917 * * *$ & 10.961 & 7.445 & 6.025 & $\begin{array}{l}\text { JP- => } \\
\text { IND- }\end{array}$ \\
\hline $\begin{array}{l}\mathrm{HK}+\neq> \\
\mathrm{IND}+\end{array}$ & $41.683 * * *$ & 10.111 & 7.277 & 5.749 & $\begin{array}{l}\mathrm{HK}+=> \\
\text { IND+ }\end{array}$ \\
\hline $\begin{array}{l}\text { HK- } \neq> \\
\text { IND- }\end{array}$ & $26.765 * * *$ & 13.360 & 9.924 & 8.069 & $\begin{array}{l}\text { HK- => } \\
\text { IND- }\end{array}$ \\
\hline $\begin{array}{l}\text { UK+ } \neq> \\
\text { IND+ }\end{array}$ & $53.587 * * *$ & 10.965 & 7.782 & 6.168 & $\begin{array}{l}\text { UK+ }+> \\
\text { IND+ }\end{array}$ \\
\hline $\begin{array}{l}\text { UK- } \neq> \\
\text { IND- }\end{array}$ & $53.438 * * *$ & 13.863 & 9.693 & 7.613 & $\begin{array}{l}\text { UK- => } \\
\text { IND- }\end{array}$ \\
\hline $\begin{array}{l}\text { FRA }+\neq> \\
\text { IND+ }\end{array}$ & $38.905 * * *$ & 11.412 & 7.999 & 6.218 & $\begin{array}{l}\text { FRA+ => } \\
\text { IND+ }\end{array}$ \\
\hline $\begin{array}{l}\text { FRA- } \neq> \\
\text { HK- }\end{array}$ & $43.475 * * *$ & 14.525 & 9.195 & 7.406 & $\begin{array}{l}\text { FRA- => } \\
\text { HK- }\end{array}$ \\
\hline $\begin{array}{l}\text { GER+ } \neq> \\
\text { IND+ }\end{array}$ & $22.995 * * *$ & 9.869 & 6.119 & 4.537 & $\begin{array}{l}\text { GER+ => } \\
\text { IND+ }\end{array}$ \\
\hline $\begin{array}{l}\text { GER- } \neq> \\
\text { IND- }\end{array}$ & $64.396 * * *$ & 12.379 & 9.619 & 7.713 & $\begin{array}{l}\text { GER- => } \\
\text { IND- }\end{array}$ \\
\hline $\begin{array}{l}\text { US }+\neq> \\
\text { IND+ }\end{array}$ & $90.172 * * *$ & 8.079 & 5.579 & 4.281 & $\begin{array}{l}\text { US+=> } \\
\text { IND+ }\end{array}$ \\
\hline US- $\neq>$ & $153.235^{* * *}$ & 13.823 & 9.045 & 7.600 & US- => \\
\hline
\end{tabular}




\begin{tabular}{llllll}
\hline IND- & & & & & IND- \\
\hline $\begin{array}{l}\text { CAN+ } \neq> \\
\text { IND+ }\end{array}$ & $72.663^{* * *}$ & 9.696 & 6.027 & 4.271 & $\begin{array}{l}\text { CAN+ => } \\
\text { IND+ }\end{array}$ \\
\hline $\begin{array}{lllll}\text { CAN- } \neq> \\
\text { IND- }\end{array}$ & $108.346^{* * *}$ & 14.351 & 9.258 & 7.416 & $\begin{array}{l}\text { CAN- => } \\
\text { IND- }\end{array}$ \\
\hline
\end{tabular}

Panel E: UK as the domestic market

\begin{tabular}{|c|c|c|c|c|c|}
\hline Hypothesis & Test Value & $\begin{array}{l}\text { Bootstrap } \\
\text { CV at } 1 \%\end{array}$ & $\begin{array}{l}\text { Bootstrap } \\
\text { CV at 5\% }\end{array}$ & $\begin{array}{l}\text { Bootstrap } \\
\text { CV at } 10 \%\end{array}$ & Conclusions \\
\hline $\begin{array}{l}\mathrm{CHN}+\neq> \\
\mathrm{UK}+\end{array}$ & $7.719 * *$ & 8.461 & 5.532 & 4.255 & $\begin{array}{l}\mathrm{CHN}+=> \\
\mathrm{UK}+\end{array}$ \\
\hline $\begin{array}{l}\text { CHN- } \neq> \\
\text { UK- }\end{array}$ & 3.438 & 14.456 & 9.669 & 7.979 & $\begin{array}{l}\text { CHN- } \neq> \\
\text { UK- }\end{array}$ \\
\hline $\begin{array}{l}\mathrm{JP}+\neq> \\
\mathrm{UK}+\end{array}$ & 1.222 & 11.834 & 6.216 & 4.351 & $\begin{array}{l}\mathrm{JP}+\neq> \\
\mathrm{UK}+\end{array}$ \\
\hline $\begin{array}{l}\text { JP- } \neq> \\
\text { UK- }\end{array}$ & $10.729 * *$ & 14.768 & 10.259 & 8.271 & $\begin{array}{l}\text { JP- }=> \\
\text { UK- }\end{array}$ \\
\hline $\begin{array}{l}\text { IND }+\neq> \\
\mathrm{UK}+\end{array}$ & $18.487 * * *$ & 11.689 & 8.192 & 5.924 & $\begin{array}{l}\text { IND+ => } \\
\text { UK+ }\end{array}$ \\
\hline $\begin{array}{l}\text { IND- } \neq> \\
\text { UK- }\end{array}$ & 3.988 & 15.615 & 9.837 & 8.110 & $\begin{array}{l}\text { IND- } \neq> \\
\text { UK- }\end{array}$ \\
\hline $\begin{array}{l}\mathrm{HK}+\neq> \\
\mathrm{UK}+\end{array}$ & $26.968 * * *$ & 11.567 & 8.359 & 6.572 & $\begin{array}{l}\mathrm{HK}+=> \\
\mathrm{UK}+\end{array}$ \\
\hline $\begin{array}{l}\text { HK- } \neq> \\
\text { UK- }\end{array}$ & 3.537 & 14.601 & 9.548 & 7.837 & $\begin{array}{l}\text { HK- } \neq> \\
\text { UK- }\end{array}$ \\
\hline $\begin{array}{l}\mathrm{FRA}+\neq> \\
\mathrm{UK}+\end{array}$ & 1.329 & 5.823 & 3.587 & 2.579 & $\begin{array}{l}\text { FRA }+\neq> \\
\text { UK+ }\end{array}$ \\
\hline $\begin{array}{l}\text { FRA- } \neq> \\
\text { UK- }\end{array}$ & $9.523^{*}$ & 12.649 & 9.634 & 7.677 & $\begin{array}{l}\text { FRA- => } \\
\text { UK- }\end{array}$ \\
\hline $\begin{array}{l}\text { GER }+\neq> \\
\mathrm{UK}+\end{array}$ & $9.348 * * *$ & 8.654 & 5.795 & 4.401 & $\begin{array}{l}\text { GER+ => } \\
\text { UK+ }\end{array}$ \\
\hline $\begin{array}{l}\text { GER- } \neq> \\
\text { UK- }\end{array}$ & 3.724 & 13.978 & 9.002 & 7.584 & $\begin{array}{l}\text { GER- } \neq> \\
\text { UK- }\end{array}$ \\
\hline $\begin{array}{l}\text { US }+\neq> \\
\text { UK+ }\end{array}$ & $316.435 * * *$ & 15.657 & 10.186 & 7.946 & $\begin{array}{l}\mathrm{US}+=> \\
\mathrm{UK}+\end{array}$ \\
\hline $\begin{array}{l}\text { US- } \neq> \\
\text { UK- }\end{array}$ & $300.883 * * *$ & 14.570 & 9.608 & 7.681 & $\begin{array}{l}\text { US- => } \\
\text { UK- }\end{array}$ \\
\hline $\begin{array}{l}\mathrm{CAN}+\neq> \\
\mathrm{UK}+\end{array}$ & $132.600 * * *$ & 13.270 & 9.499 & 7.759 & $\begin{array}{l}\mathrm{CAN}+=> \\
\mathrm{UK}+\end{array}$ \\
\hline $\begin{array}{l}\text { CAN- } \neq> \\
\text { UK- }\end{array}$ & $137.183 * * *$ & 14.060 & 9.930 & 7.838 & $\begin{array}{l}\text { CAN- => } \\
\text { UK- }\end{array}$ \\
\hline
\end{tabular}

Panel F: France as the domestic market

\begin{tabular}{llllll}
\hline Hypothesis & Test Value & $\begin{array}{l}\text { Bootstrap } \\
\text { CV at 1\% }\end{array}$ & $\begin{array}{l}\text { Bootstrap } \\
\text { CV at 5\% }\end{array}$ & $\begin{array}{l}\text { Bootstrap } \\
\text { CV at 10\% }\end{array}$ & Conclusions \\
\hline
\end{tabular}




\begin{tabular}{|c|c|c|c|c|c|}
\hline $\begin{array}{l}\mathrm{CHN}+\neq> \\
\text { FRA+ }\end{array}$ & $5.769 * *$ & 8.259 & 5.490 & 4.467 & $\begin{array}{l}\mathrm{CHN}+=> \\
\text { FRA+ }\end{array}$ \\
\hline $\begin{array}{l}\text { CHN- } \neq> \\
\text { FRA- }\end{array}$ & 6.506 & 13.484 & 9.604 & 7.599 & $\begin{array}{l}\text { CHN- } \neq> \\
\text { FRA- }\end{array}$ \\
\hline $\begin{array}{l}\mathrm{JP}+\neq> \\
\text { FRA+ }\end{array}$ & 2.607 & 10.066 & 6.341 & 4.767 & $\begin{array}{l}\text { JP }+\neq> \\
\text { FRA }+\end{array}$ \\
\hline $\begin{array}{l}\text { JP- } \neq> \\
\text { FRA- }\end{array}$ & 7.519 & 14.341 & 9.479 & 7.844 & $\begin{array}{l}\text { JP- } \neq> \\
\text { FRA- }\end{array}$ \\
\hline $\begin{array}{l}\text { IND }+\neq> \\
\text { FRA }+\end{array}$ & $11.646^{* *}$ & 12.588 & 8.512 & 6.249 & $\begin{array}{l}\text { IND+ => } \\
\text { FRA+ }\end{array}$ \\
\hline $\begin{array}{l}\text { IND- } \neq> \\
\text { FRA- }\end{array}$ & $12.665 * *$ & 15.215 & 10.034 & 7.687 & $\begin{array}{l}\text { IND- => } \\
\text { FRA- }\end{array}$ \\
\hline $\begin{array}{l}\text { HK }+\neq> \\
\text { FRA }+\end{array}$ & $21.509 * * *$ & 11.769 & 8.396 & 6.757 & $\begin{array}{l}\text { HK+ => } \\
\text { FRA+ }\end{array}$ \\
\hline $\begin{array}{l}\text { HK- } \neq> \\
\text { FRA- }\end{array}$ & $10.187 * *$ & 13.552 & 9.743 & 7.632 & $\begin{array}{l}\text { HK- => } \\
\text { FRA- }\end{array}$ \\
\hline $\begin{array}{l}\mathrm{UK}+\neq> \\
\text { FRA }+\end{array}$ & $5.048 * *$ & 6.041 & 3.670 & 2.820 & $\begin{array}{l}\mathrm{UK}+=> \\
\text { FRA }+\end{array}$ \\
\hline $\begin{array}{l}\text { UK- } \neq> \\
\text { FRA- }\end{array}$ & $36.438 * * *$ & 0.001 & 0.000 & 0.000 & $\begin{array}{l}\text { UK- => } \\
\text { FRA- }\end{array}$ \\
\hline $\begin{array}{l}\text { GER }+\neq> \\
\text { FRA }+\end{array}$ & $25.755 * * *$ & 9.621 & 5.937 & 4.512 & $\begin{array}{l}\text { GER+ => } \\
\text { FRA+ }\end{array}$ \\
\hline $\begin{array}{l}\text { GER- } \neq> \\
\text { FRA- }\end{array}$ & $32.963 * * *$ & 12.736 & 9.109 & 7.456 & $\begin{array}{l}\text { GER- => } \\
\text { FRA- }\end{array}$ \\
\hline $\begin{array}{l}\text { US }+\neq> \\
\text { FRA }+\end{array}$ & $261.880 * * *$ & 14.662 & 9.520 & 7.642 & $\begin{array}{l}\text { US+ => } \\
\text { FRA+ }\end{array}$ \\
\hline $\begin{array}{l}\text { US- } \neq> \\
\text { FRA- }\end{array}$ & $283.408 * * *$ & 14.566 & 9.395 & 7.777 & $\begin{array}{l}\text { US- => } \\
\text { FRA- }\end{array}$ \\
\hline $\begin{array}{l}\text { CAN+ } \neq> \\
\text { FRA+ }\end{array}$ & $79.023 * * *$ & 10.342 & 5.893 & 4.387 & $\begin{array}{l}\text { CAN+ => } \\
\text { FRA+ }\end{array}$ \\
\hline $\begin{array}{l}\text { CAN- } \neq> \\
\text { FRAK- }\end{array}$ & $138.817 * * *$ & 12.851 & 9.846 & 7.793 & $\begin{array}{l}\text { CAN- => } \\
\text { FRAK- }\end{array}$ \\
\hline
\end{tabular}

Panel G: Germany as the domestic market

\begin{tabular}{llllll}
\hline Hypothesis & Test Value & $\begin{array}{l}\text { Bootstrap } \\
\text { CV at } 1 \%\end{array}$ & $\begin{array}{l}\text { Bootstrap } \\
\text { CV at } 5 \%\end{array}$ & $\begin{array}{l}\text { Bootstrap } \\
\text { CV at 10\% }\end{array}$ & Conclusions \\
\hline $\begin{array}{l}\text { CHN+ } \neq> \\
\text { GER+ }\end{array}$ & $7.124 * *$ & 8.896 & 5.712 & 4.575 & $\begin{array}{l}\text { CHN+ }=> \\
\text { GER+ }\end{array}$ \\
\hline $\begin{array}{l}\text { CHN- } \neq> \\
\text { GER- }\end{array}$ & 5.234 & 13.358 & 9.204 & 7.574 & $\begin{array}{l}\text { CHN- } \neq> \\
\text { GER- }\end{array}$ \\
\hline $\begin{array}{l}\text { JP+ } \neq> \\
\text { GER+ }\end{array}$ & 0.949 & 10.373 & 6.478 & 5.081 & $\begin{array}{l}\text { JP }+\neq> \\
\text { GER+ }\end{array}$ \\
\hline $\begin{array}{l}\text { JP- } \neq> \\
\text { GER- }\end{array}$ & 3.504 & 14.174 & 9.462 & 7.670 & $\begin{array}{l}\text { JP- } \neq> \\
\text { GER- }\end{array}$ \\
\hline $\begin{array}{l}\text { IND } \neq \neq> \\
\text { GER+ }\end{array}$ & $8.862 * *$ & 8.954 & 5.962 & 4.759 & $\begin{array}{l}\text { IND }+> \\
\text { GER+ }\end{array}$ \\
\hline IND- $\neq>$ & 4.454 & 13.777 & 9.755 & 7.785 & IND- $\neq>$ \\
\hline
\end{tabular}




\begin{tabular}{|c|c|c|c|c|c|}
\hline GER- & & & & & GER- \\
\hline $\begin{array}{l}\mathrm{HK}+\neq> \\
\mathrm{GER}+\end{array}$ & $132.475^{* * *}$ & 14.092 & 9.908 & 8.130 & $\begin{array}{l}\mathrm{HK}+=> \\
\text { GER+ }\end{array}$ \\
\hline $\begin{array}{l}\text { HK- } \neq> \\
\text { GER- }\end{array}$ & $201.710^{* * *}$ & 13.070 & 9.386 & 7.788 & $\begin{array}{l}\text { HK- => } \\
\text { GER- }\end{array}$ \\
\hline $\begin{array}{l}\text { FRA }+\neq> \\
\text { GER+ }\end{array}$ & $7.633 * *$ & 9.565 & 6.434 & 4.614 & $\begin{array}{l}\text { FRA+ => } \\
\text { GER+ }\end{array}$ \\
\hline $\begin{array}{l}\text { FRA- } \neq> \\
\text { GER- }\end{array}$ & $28.509 * * *$ & 12.218 & 9.068 & 7.537 & $\begin{array}{l}\text { FRA- => } \\
\text { GER- }\end{array}$ \\
\hline $\begin{array}{l}\mathrm{UK}+\neq> \\
\text { GER+ }\end{array}$ & $4.902 *$ & 9.796 & 6.317 & 4.818 & $\begin{array}{l}\text { UK+ => } \\
\text { GER+ }\end{array}$ \\
\hline $\begin{array}{l}\text { UK- } \neq> \\
\text { GER- }\end{array}$ & $11.414 * * *$ & 11.411 & 7.562 & 6.202 & $\begin{array}{l}\text { UK- => } \\
\text { GER- }\end{array}$ \\
\hline $\begin{array}{l}\text { US+ } \neq> \\
\text { GER+ }\end{array}$ & $132.475^{* * *}$ & 14.092 & 9.908 & 8.130 & $\begin{array}{l}\text { US }+=> \\
\text { GER+ }\end{array}$ \\
\hline $\begin{array}{l}\text { US- } \neq> \\
\text { GER- }\end{array}$ & $201.710 * * *$ & 13.070 & 9.386 & 7.788 & $\begin{array}{l}\text { US- => } \\
\text { GER- }\end{array}$ \\
\hline $\begin{array}{l}\text { CAN }+\neq> \\
\text { GER+ }\end{array}$ & $32.205 * * *$ & 8.472 & 5.823 & 4.288 & $\begin{array}{l}\text { CAN+ => } \\
\text { GER+ }\end{array}$ \\
\hline $\begin{array}{l}\text { CAN- } \neq> \\
\text { GER- }\end{array}$ & $104.353 * * *$ & 13.780 & 9.697 & 7.749 & $\begin{array}{l}\text { CAN- => } \\
\text { GER- }\end{array}$ \\
\hline
\end{tabular}

Panel H: US as the domestic market

\begin{tabular}{|c|c|c|c|c|c|}
\hline Hypothesis & Test Value & $\begin{array}{l}\text { Bootstrap } \\
\mathrm{CV} \text { at } 1 \%\end{array}$ & $\begin{array}{l}\text { Bootstrap } \\
\mathrm{CV} \text { at } 5 \%\end{array}$ & $\begin{array}{l}\text { Bootstrap } \\
\mathrm{CV} \text { at } 10 \%\end{array}$ & Conclusions \\
\hline $\begin{array}{l}\mathrm{CHN}+\neq> \\
\mathrm{US}+\end{array}$ & 7.401 & 13.167 & 9.343 & 7.755 & $\begin{array}{l}\mathrm{CHN}+\neq> \\
\mathrm{US}+\end{array}$ \\
\hline $\begin{array}{l}\text { CHN- } \neq> \\
\text { US- }\end{array}$ & $9.758 * *$ & 12.700 & 9.187 & 7.339 & $\begin{array}{l}\text { CHN- => } \\
\text { US- }\end{array}$ \\
\hline $\begin{array}{l}\mathrm{JP}+\neq> \\
\mathrm{US}+\end{array}$ & 2.692 & 13.299 & 9.897 & 7.916 & $\begin{array}{l}\mathrm{JP}+\neq> \\
\mathrm{US}+\end{array}$ \\
\hline $\begin{array}{l}\text { JP- } \neq> \\
\text { US- }\end{array}$ & $11.195 * *$ & 14.465 & 9.826 & 7.765 & $\begin{array}{l}\text { JP- }=> \\
\text { US- }\end{array}$ \\
\hline $\begin{array}{l}\text { IND }+\neq> \\
\mathrm{US}+\end{array}$ & 0.064 & 8.980 & 5.952 & 4.560 & $\begin{array}{l}\text { IND }+\neq> \\
\text { US+ }\end{array}$ \\
\hline $\begin{array}{l}\text { IND- } \neq> \\
\text { US- }\end{array}$ & $9.670^{*}$ & 13.987 & 10.109 & 7.511 & $\begin{array}{l}\text { IND- => } \\
\text { US- }\end{array}$ \\
\hline $\begin{array}{l}\mathrm{HK}+\neq> \\
\mathrm{US}+\end{array}$ & 2.124 & 13.259 & 9.055 & 7.461 & $\begin{array}{l}\mathrm{HK}+\neq> \\
\mathrm{US}+\end{array}$ \\
\hline $\begin{array}{l}\text { HK- } \neq> \\
\text { US- }\end{array}$ & $22.329 * * *$ & 14.516 & 10.191 & 7.858 & $\begin{array}{l}\text { HK- => } \\
\text { US- }\end{array}$ \\
\hline $\begin{array}{l}\mathrm{UK}+\neq> \\
\mathrm{US}+\end{array}$ & $8.073^{*}$ & 14.167 & 9.164 & 7.560 & $\begin{array}{l}\mathrm{UK}+=> \\
\mathrm{US}+\end{array}$ \\
\hline $\begin{array}{l}\text { UK- } \neq> \\
\text { US- }\end{array}$ & $56.113 * * *$ & 13.274 & 9.585 & 7.799 & $\begin{array}{l}\text { UK- => } \\
\text { US- }\end{array}$ \\
\hline $\begin{array}{l}\mathrm{FRA}+\neq> \\
\mathrm{US}+\end{array}$ & 7.774* & 13.429 & 9.475 & 7.503 & $\begin{array}{l}\text { FRA+ => } \\
\text { US+ }\end{array}$ \\
\hline
\end{tabular}




\begin{tabular}{lccccl}
\hline $\begin{array}{l}\text { FRA- } \neq> \\
\text { US- }\end{array}$ & $19.572 * * *$ & 14.005 & 9.436 & 7.564 & $\begin{array}{l}\text { FRA- } \\
\text { US- }\end{array}$ \\
\hline $\begin{array}{l}\text { GER+ } \neq> \\
\text { US+ }\end{array}$ & 4.726 & 14.241 & 9.771 & 7.739 & $\begin{array}{l}\text { GER+ } \neq> \\
\text { US+ }\end{array}$ \\
\hline $\begin{array}{l}\text { GER- } \neq> \\
\text { US- }\end{array}$ & $38.291 * * *$ & 14.802 & 9.487 & 7.599 & $\begin{array}{l}\text { GER- }=> \\
\text { US- }\end{array}$ \\
\hline $\begin{array}{l}\text { CAN+ } \neq> \\
\text { US+ }\end{array}$ & $22.868^{* * *}$ & 14.878 & 10.020 & 8.140 & $\begin{array}{l}\text { CAN+ }=> \\
\text { US+ }\end{array}$ \\
\hline $\begin{array}{l}\text { CAN- } \neq> \\
\text { US- }\end{array}$ & $25.200 * * *$ & 10.022 & 5.905 & 4.017 & $\begin{array}{l}\text { CAN- }=> \\
\text { US- }\end{array}$ \\
\hline
\end{tabular}

Panel I: Canada as the domestic market

\begin{tabular}{|c|c|c|c|c|c|}
\hline Hypothesis & Test Value & $\begin{array}{l}\text { Bootstrap } \\
\text { CV at } 1 \%\end{array}$ & $\begin{array}{l}\text { Bootstrap } \\
\text { CV at 5\% }\end{array}$ & $\begin{array}{l}\text { Bootstrap } \\
\text { CV at } 10 \%\end{array}$ & Conclusions \\
\hline $\begin{array}{l}\mathrm{CHN}+\neq> \\
\mathrm{CAN}+\end{array}$ & 1.994 & 8.769 & 5.629 & 4.416 & $\begin{array}{l}\mathrm{CHN}+\neq> \\
\mathrm{CAN}+\end{array}$ \\
\hline $\begin{array}{l}\text { CHN- } \neq> \\
\text { CAN- }\end{array}$ & 4.103 & 12.718 & 9.029 & 7.745 & $\begin{array}{l}\text { CHN- } \neq> \\
\text { CAN- }\end{array}$ \\
\hline $\begin{array}{l}\mathrm{JP}+\neq> \\
\mathrm{CAN}+\end{array}$ & $8.144 * *$ & 10.290 & 5.770 & 4.381 & $\begin{array}{l}\mathrm{JP}+=> \\
\mathrm{CAN}+\end{array}$ \\
\hline $\begin{array}{l}\text { JP- } \neq> \\
\text { CAN- }\end{array}$ & $12.156 * *$ & 13.357 & 10.247 & 7.895 & $\begin{array}{l}\text { JP- }=> \\
\text { CAN- }\end{array}$ \\
\hline $\begin{array}{l}\text { IND }+\neq> \\
\text { CAN }+\end{array}$ & $15.463 * * *$ & 9.381 & 6.025 & 4.656 & $\begin{array}{l}\text { IND+ => } \\
\text { CAN+ }\end{array}$ \\
\hline $\begin{array}{l}\text { IND- } \neq> \\
\text { CAN- }\end{array}$ & $16.045 * * *$ & 14.231 & 9.466 & 7.922 & $\begin{array}{l}\text { IND- => } \\
\text { CAN- }\end{array}$ \\
\hline $\begin{array}{l}\mathrm{HK}+\neq> \\
\mathrm{CAN}+\end{array}$ & $33.838 * * *$ & 12.847 & 8.248 & 6.384 & $\begin{array}{l}\mathrm{HK}+=> \\
\mathrm{CAN}+\end{array}$ \\
\hline $\begin{array}{l}\text { HK- } \neq> \\
\text { CAN- }\end{array}$ & $20.134 * * *$ & 14.689 & 10.581 & 8.349 & $\begin{array}{l}\text { HK- }=> \\
\text { CAN- }\end{array}$ \\
\hline $\begin{array}{l}\mathrm{UK}+\neq> \\
\mathrm{CAN}+\end{array}$ & $52.231 * * *$ & 12.869 & 9.331 & 7.518 & $\begin{array}{l}\mathrm{UK}+=> \\
\mathrm{CAN}+\end{array}$ \\
\hline $\begin{array}{l}\text { UK- } \neq> \\
\text { CAN- }\end{array}$ & $54.154 * * *$ & 13.143 & 9.345 & 7.975 & $\begin{array}{l}\text { UK- => } \\
\text { CAN- }\end{array}$ \\
\hline $\begin{array}{l}\mathrm{FRA}+\neq> \\
\mathrm{CAN}+\end{array}$ & $40.605 * * *$ & 9.507 & 5.938 & 4.478 & $\begin{array}{l}\text { FRA+ => } \\
\text { CAN+ }\end{array}$ \\
\hline $\begin{array}{l}\text { FRA- } \neq> \\
\text { CAN- }\end{array}$ & $18.424 * * *$ & 13.248 & 9.685 & 8.078 & $\begin{array}{l}\text { FRA- => } \\
\text { CAN- }\end{array}$ \\
\hline $\begin{array}{l}\text { GER }+\neq> \\
\text { CAN }+\end{array}$ & $50.013 * * *$ & 8.918 & 5.650 & 4.604 & $\begin{array}{l}\text { GER+ => } \\
\text { CAN+ }\end{array}$ \\
\hline $\begin{array}{l}\text { GER- } \neq> \\
\text { CAN- }\end{array}$ & $33.351 * * *$ & 13.523 & 9.716 & 7.600 & $\begin{array}{l}\text { GER- => } \\
\text { CAN- }\end{array}$ \\
\hline $\begin{array}{l}\text { US }+\neq> \\
\text { CAN+ }\end{array}$ & $116.790 * * *$ & 14.505 & 9.370 & 7.727 & $\begin{array}{l}\text { US+ => } \\
\text { CAN+ }\end{array}$ \\
\hline $\begin{array}{l}\text { US- } \neq> \\
\text { CAN- }\end{array}$ & $34.149 * * *$ & 15.281 & 9.193 & 7.567 & $\begin{array}{l}\text { US- => } \\
\text { CAN- }\end{array}$ \\
\hline
\end{tabular}




\section{References:}

Bouri, E., Gupta, R., Hosseini, S., \& Lau, C. K. M. (2017). Does Global Fear Predict Fear in BRICS Stock Markets? Evidence from a Bayesian Graphical VAR Model. Emerging Markets Review.

Chen, P. (2017). Understanding international stock market comovements: A comparison of developed and emerging markets. International Review of Economics \& Finance.

Climent, F., Meneu, V., (2003). Has (1997). Asian Crisis Increased Information Flows between International Markets. International Review of Economics \& Finance 12, 111-143.

Connolly, R.A., Wang, F.A., (2003). International Equity Market Comovements: Economic Fundamentals or Contagion? Pacific-Basin Finance Journal 11, $23-43$.

Engle, R.F., Ito, T., Lin, W.-L., (1990). Meteor Showers or Heat Waves? Heteroskedastic Intra-daily Volatility in the Foreign Exchange Market. Econometrica 58, 525-542.

Gebka, B., Serwa, D., (2007). Intra- and Inter-regional Spillovers between Emerging Capital Markets around the World. Research in International Business and Finance 21, 203-221.

Hamao, Y., Masulis, R., Ng, V., (1991). The Effect of the 1987 Stock Crash on International Financial Integration, in: Ziemba, W.T., Bailey, W., Hamao, Y.R. (Eds.), Japanese Financial Market Research. North Holland, Amsterdam, pp. 1-20.

Engle, R., Ito, T., \& Lin, W. L. (1990). Meteor Showers or Heat Waves? Heteroskedastic Intra-daily Volatility in the Foreign Exchange Market. Econometrica, 58(3), 525-42.

Hamilton, J., (2010). Macroeconomics and ARCH, in: Bollerslev, T., Russell, J.R., Watson, M. (Eds.), Festschrift in Honor of Robert F. Engle. Oxford University Press, Oxford, pp. 7996.

Hatemi-J, A. (2003). A new method to choose optimal lag order in stable and unstable VAR models. Applied Economics Letters, 10(3), 135-137.

Hatemi-j, A. (2012). Asymmetric causality tests with an application. Empirical Economics, 110.

Hsin, C.-W., (2004). A Multilateral Approach to Examining the Comovements among Major World Equity Markets. International Review of Financial Analysis 13, 433-462.

Huang, B.-N., Yang, C.-W., Hu, J.W.-S., (2000). Causality and Cointegration of Stock Markets among the United States, Japan and the South China Growth Triangle. International Review of Financial Analysis 9, 281-297.

Kim, S.W., Rogers, J.H., (1995). International stock price spillovers and market liberalization: Evidence from Korea, Japan and the United States. Journal of Empirical Finance 2, 117-133.

Koutmos, G., (1996). Modeling the Dynamic Interdependence of Major European Stock Markets. Journal of Business Finance \& Accounting 23, 975-988.

Koutmos, G., Booth, G.G., (1995). Asymmetric Volatility Transmission in International Stock Markets. Journal of International Money and Finance 14, 747-762. 
Kundu, S., \& Sarkar, N. (2016). Return and volatility interdependences in up and down markets across developed and emerging countries. Research in International Business and Finance, 36, 297-311.

Lee, B.-S., Rui, O.M., Wang, S.S., (2004). Information Transmission between the NASDAQ and Asian Second Board Markets. Journal of Banking \& Finance 28, 1637-1670.

Lin, W.-L., Engle, R., Ito, T., (1994). Do Bulls and Bears Move across Borders? International Transmission of Stock Returns and Volatility. Review of Financial Studies 7, 507-538.

Liu, Y., Pan, M., (1997). Mean and Volatility Spillover Effect in the U.S. and Pacific-Basin Stock Markets. Multinational Finance Journal 1, 47-62.

Masih, R., Masih, A.M.M., (2001). Long and Short Term Dynamic Causal Transmission amongst International Stock Markets. Journal of International Money and Finance 20, 563587.

Mukherjee, K.n., Mishra, R.K., (2010). Stock Market Integration and Volatility Spillover: India and its Major Asian Counterparts. Research in International Business and Finance 24, 235-251.

Nam, J.H., Yuhn, K.-h., Kim, S.B., (2008). What Happened to Pacific-basin Emerging Markets after the 1997 Financial Crisis? Applied Financial Economics 18, 639-658.

Newey, W.K., West, K.D., (1987). A Simple, Positive Semi-definite, Heteroskedasticity and Autocorrelation Consistent Covariance Matrix. Econometrica 55, 703-708.

Niarchos, N., Tse, Y., Wu, C., Young, A., (1999). International Transmission of Information: A study of the Relationship between the U.S. and Greek Stock Markets. Multinational Finance Journal 3, 19-40.

Sheng, H.-C., Tu, A.H., (2000). A Study of Cointegration and Variance Decomposition among National Equity Indices before and during the Period of the Asian Financial Crisis. Journal of Multinational Financial Management 10, 345-365.

Wang, S.S., Firth, M., (2004). Do Bears and Bulls Swim across Oceans? Market Information Transmission between Greater China and the Rest of the World. Journal of International Financial Markets, Institutions and Money 14, 235-254.

Wu, W., Lau, M. C. K., \& Vigne, S. A. (2017). Modelling asymmetric conditional dependence between Shanghai and Hong Kong stock markets. Research in International Business and Finance, 42, 1137-1149.

Yarovaya, L., Brzeszczyński, J., \& Lau, C. K. M. (2016). Intra-and inter-regional return and volatility spillovers across emerging and developed markets: Evidence from stock indices and stock index futures. International Review of Financial Analysis, 43, 96-114.

Yarovaya, L., Brzeszczyński, J., \& Lau, C. K. M. (2017). Asymmetry in spillover effects: Evidence for international stock index futures markets. International Review of Financial Analysis, 53, 94-111. 